\title{
Graham Pont $\mid$ The Education of the Classical Architect from Plato to Vitruvius
}

Plato divided science (episteme) into 'science of action' (praktike) and 'science of mere knowing' (gnostike). His argument is the first known attempt to distinguish what is now recognised as technology, as distinct from more purely rational science. Aristotle coined the compound term technologia and thereby established this new department of science within the general system of knowledge. Plato did not develop his novel characterisation of the architect any further, for the ancient Greeks did not consider architecture a fine or estimable art. The best available source of Greek architectural pedagogy is the Roman Vitruvius. Graham Pont discusses Vitruvius's distinction between the 'practical' side of architecture (fabrica) and the 'theoretical' (ratiocinatio), and examines the mathematical preparation of ancient Greek and Roman architects

In memory of Alpay Özdural

\section{Introduction}

In The Statesman (c.360 BC), Plato divided science (episteme) into 'science of action' (praktike) and 'science of mere knowing' (gnostike). His argument is the first known attempt to distinguish what is now recognised as technology, as distinct from more purely rational science, the dominant concern of his philosophical predecessors since the time of Heraclitus. Socrates, the son of a craftsman, had shown considerable interest in the practical arts (technai) and his disciple, Plato, had sought the logos of many a techne that had not previously been subjected to critical inquiry. But it was Plato's pupil, Aristotle, who coined the compound term technologia and thereby established this new department of science within the general system of knowledge. The first art to be explicitly designated a technology was rhetoric [Aristotle, Rhetorica, c. 330 BC].

Plato boldly envisaged pratike and gnostike as 'constitutive of the unity of science as a whole, ${ }^{1}$ thus anticipating Aristotle and the modern division of knowledge into 'know how' and 'know that'. In trying to illustrate the difference, Plato identified kings and architects as exemplifying a distinctive kind of practical knowledge: knowledge which is 'imperative' (or executive) rather than purely 'critical' (philosophical, scientific or mathematical), as being concerned with 'commanding' rather than just ascertaining scientific facts or calculating mathematical truths.

While reading this key passage, we must remember that the Greek expression architecton originally meant 'master builder' and that, despite their great achievements in design, planning, construction and decoration, the Greeks of Plato's time lacked an appropriate terminology to distinguish between building in general and architecture in particular.

Having drawn attention to the analogous executive roles of kings and architects, Plato drew a revolutionary conclusion:

So we may fairly say he [the architect] comes under science which is concerned with knowing.

Exactly. 
But his business, I take it, is not to deliver a judgment, and so make an end and have done, like the calculator; his task is to give each group of his workmen the requisite directions until they have executed his instructions.

True.

Thus such callings are one and all concerned with knowledge, no less than those which we may rank with computation; the difference between the two types is that between judging and commanding.

So it appears.

Then, if we distinguish, within the whole of science concerned with knowledge, between one branch which we may call imperative and another which is critical, we may claim to have made a neat division.

Yes, if I may judge.

And harmony between partners in a common task is always a thing to be thankful for

[The Statesman 260A-B]. ${ }^{2}$

It is hardly surprising that Plato did not develop his novel characterisation of the architect any further, for the ancient Greeks did not consider architecture a fine or estimable art, let alone a learned profession. For them, the constructive arts ranked well below the musico-poetical or performing arts, the principal subject of their aesthetic inquiries. The best available source of Greek architectural pedagogy is the Roman Vitruvius.

\section{Practice and theory according to Vitruvius}

At the beginning of the De architectura libri decem Vitruvius briefly rehearses the distinction between the 'practical' side of architecture (fabrica) and the 'theoretical' (ratiocinatio), as if it were an academic or professional commonplace. His opening words have been quoted, translated, annotated and discussed for centuries, yet scholars still fail to agree on the precise construction and interpretation of this passage.

Vitruvius first asserts that fabrica est continuata ac trita usus meditatio... In the most recent English translation, Ingrid D. Rowland renders fabrica here as 'Practice... the constant, repeated exercise of the hands...' [Rowland and Howe 1999, 21] —an interpretation supported by most other translators [cf. Geertman and de Jong 1989, 41]. I wish to argue, however, the identificaion of fabrica with the modern notion of 'practice' is mistaken in principle; that fabrica, as used here by Vitruvius, ${ }^{3}$ does not denote making, practical building or the art of construction; and, most emphatically, that it does not refer directly to any kind of manual art. Vitruvius's concept of ratiocinatio has proved elusive too; but both of these problematic terms are greatly illuminated by Plato's pioneering analysis of architectural knowledge.

Despite their profound differences of culture and intellect, Plato and Vitruvius characterise the architect in very similar terms, not as an illiterate manual worker or hired artisan but as an educated executive whose intellectual qualifications include an understanding of practical building as well as a knowledge of pure sciences. The parallelism can be represented as follows:

\begin{tabular}{|l|c|c|}
\hline \multicolumn{2}{|c|}{ PRINCIPAL DIVISIONS OF ARCHITECTURAL KNOWLEDGE } \\
\hline Plato & Praktike & Gnostike \\
\hline Vitruvius & Fabrica & Ratiocinatio \\
\hline
\end{tabular}


For Plato, the architect's praktike and gnostike are both kinds of intellectual knowledge, requiring no manual skill (except, perhaps, ancillary arts of the pen such as writing, calculating and drafting); and Vitruvius's own words make it abundantly clear that fabrica is also an intellectual process which he calls meditatio. So to render fabrica as 'practice', 'craftsmanship' or pratique de la construction [Callebat and Fleury 1995, 67] wrongly suggests that the term here refers to mere dexterity and 'hands-on' knowledge.

Among the English translators, Joseph Gwilt (long considered the best) is exceptional in recognising that fabrica primarily means 'frequent and continued contemplation' (meditatio) ${ }^{4}$ of the arts associated with building. Meditatio is strictly mental-the subjective act of contemplation or architectural thinking. ${ }^{5}$ Thus fabrica yields the kind of professional knowledge and experience that is derived from thoughtful study of, though not necessarily practical engagement in, the various constructive arts. In essence, fabrica is not 'hands-on' knowledge at all, though it can be, and normally is, acquired through direct involvement in building and related crafts.

Fabrica, for Vitruvius, is the practice of architectural contemplation. By extension it comes to embrace both the process and the product of architectural contemplation - the practical 'know how' of surveying, site-analysis, design, planning, calculation and management, rather than the muscular and intuitive grasp of actual building that few architects experience today. Fabrica therefore includes the distinctive kind of professional knowledge - the understanding of and feel for the business of architecture - that students begin to acquire from their lectures, textbooks and exercises in the studio, and later go on to augment and enrich through experience on the job. ${ }^{6}$ All this is a long way from modern derivatives like 'fabric' and 'fabrication'.

Once the epistemological status of fabrica is grasped, the parallel with Plato's praktike becomes apparent: the art of architecture requires education in executive or goal-directed knowledge ('know how') as well as pure science ('know that'). Both theorists in fact conceive practical architecture in the way that the ancients regarded practical music, which was traditionally distinguished, on the one hand, from purely theoretical or speculative music (the physics, mathematics and metaphysics of sound) and, on the other, from the manual art of performing (part of musica instrumentalis):

Practical Musick shews how the principles are to be applied, or how sounds in the relation they bear to Musick may be ordered, and variously put together in consonance or succession, so as to answer the end. And this is what we call the art of composition, which is properly the practical part of Musick [Hoyle 1770, 62].

Accordingly a composer could be trained as a 'practical' musician, without ever having acquired the manual art of instrumental performance, just as a person without any practical building skills can still be legally designated an 'architect'. It is possible-I think, very likely-that the once preeminent discipline of music provided the original model for Plato's new executive architect; ${ }^{7}$ but the earliest extant source of the distinction between theoretical and practical music is the eclectic compiler Aristides Quintilianus, of uncertain date (late third-early fourth century AD?) [cf. Mathiesen 1983, 16-17, 74f.].

\section{Ratio and proportion in architecture}

The Roman term ratio and all its derivatives go back to the Greek logos, which became a fundamental concept of Western philosophy and science. From its core meaning of 'word' or 'number', logos acquired a bewildering range of technical meanings, including 'theory', 'explanation', 'definition', 'principle', 'reason', 'ratio' (in the mathematical sense) and so on. When Socrates baffled his fellow Athenians by asking them for the logos of justice, piety, temperance,

78 Graham PONT- The Education of the Classical Architect from Plato to Vitruvius 
courage etc., he was seeking a 'logical' definition of these terms - what his successors would call the 'ratio' and, later, the 'rationale'. Hence Vitruvius's ratiocination; but his definition of this term has also caused endless problems: Ratiocinatio autem est, quae res fabricatas sollertiae ac rationis proportione demonstrare atque explicare potest. This is the Loeb version of the text which Granger renders as, 'Technology sets forth and explains things wrought in accordance with technical skill and method' [Granger 1962 I, 7]. Morgan however has it that 'Theory... is the ability to demonstrate and explain the productions of dexterity on the principles of proportion' [Hickey 1960,5]. Somewhere in between is Gwilt with 'Theory is the result of that reasoning which demonstrates and explains that the material wrought has been so converted so to answer the end proposed' [Gwilt 1826: 3].

These seemingly irreconciliable differences among the translators are partly explained by their failure to agree on how the sentence should be construed. The Romans did not use punctuation, without which Vitruvius's sentence remains ambiguous. Choisy inserts commas, to separate and subordinate the phrase sollertiae ac rationis pro portione, as well as dividing proportione into two words. He translates the definition of ratiocinatio thus:

Quant à la Théorie:

C'est ce qui peut démontrer et expliquer, à la mesure de le pénétration de la raison, les qui s'executent [Choisy 1971, 5].

This makes good sense in itself but it is not a complete translation of Vitruvius's own words. It does not take account of sollertiae: sollertia has a range of possible meanings, from 'technical skill' and 'dexterity' to 'expertness' and even 'science'. ${ }^{8}$ But if Choisy has construed this passage correctly, the subordinate phrase would be better translated as in accordance with [the architect's] skill [sollertiae] and reasoning power [rationis]'. Thus interpreted, Vitruvius could be understood as deliberately contraposing two basic forms of knowledge, very like Plato's praktike and gnostike.'

This interpretation, however, is radically different from Granger's, which omits the commas and makes res fabricatas sollertiae ac rationis proportione the object of the phrase demonstrare atque explicare potest. But his clever translation of rationcinatio as 'technology' seriously misrepresents the kind of knowledge Vitruvius was actually referring to. Ratiocinatio, like logos, has connotations of exact science and speculative theory but 'technology', as Granger has it, degrades the core meaning of 'ratio' by making it merely descriptive or empirical rather than speculative knowledge. Perhaps 'technology'-literally, the theory of art-might have made a better translation of fabrica than ratiocination! Granger's translation fails, moreover, to bring out the intended antithesis of meditatio (contemplation of the arts) and ratiocinatio (speculative theory and scientific explanation of the arts). This is not the same as the more common-sense distinction between craftsmanship and technology.

If, alternatively, the definition of ratiocinatio is to be interpreted along the lines suggested by Choisy, there emerges a subtlety he missed too: if sollertiae ac rationis is translated as in accordance with [the architect's] skill and reasoning power', then Vitruvius would certainly appear to be endorsing no less than Plato's original antithesis between the two kinds of architectural 'science': on the one hand, empirical knowledge, professional skill and experience (sollertia or episteme praktike) and, on the other, mathematical science and speculative theory (ratiocinatio or episteme gnostike).

Vitruvius's contrast would now seem to match perfectly Plato's division of the architect's science into 'imperative' knowledge - the executive skills and expertise needed to get the job done 
- and his 'critical' knowledge, which is more purely theoretical, mathematical or speculative. It was Aristotle who, with characteristic genius, systematised the distinction between episteme praktike and episteme theoretike [Ross 1954: 1139b3], which, it must again be emphasised, is not the same as the modern opposition of 'practice' and 'theory'. ${ }^{10}$

But, as well as radically disagreeing on the nature of 'practical' architecture, the translators have failed to reach a consensus on the significance of proportione in Vitruvius's definition. The problem is highlighted by comparing the best known English translations of the phrase res fabricatas sollertiae ac rationis proportione.

Granger has 'things wrought in accord with technical skill and method'; whereas Morgan has 'productions of dexterity on the principles of proportion' and Rowland, similarly, has 'the proportions of completed works...' [Rowland and Howe 1999, 21]. The crucial question here is whether Vitruvius, as Granger has read him, is using proportione in a theoretically neutral sense, as equivalent to Choisy's pro portione (a la mesure or 'to the appropriate degree'); ${ }^{11}$ or whether, as Morgan assumes, the word is being used in a technical sense to refer to the architect's special knowledge of and skill in the use of mathematical proportions. ${ }^{12}$

Vitruvius's language is again hopelessly ambiguous and his actual intention remains unclear. If, however, he was an heir of the Platonic tradition, it would be difficult to accept that the first mention of proportione in the Ten Books is an accident of grammar ${ }^{13}$ rather than a matter of substance - especially when it prefaces a work full of precise detail on the proportions of the classical orders.

\section{Mathematics for the classical architect}

According to Plato's system of higher education, which is outlined in both the Republic [VII, 527-531] and the Laws [VII, 817-822], the first academic curriculum consisted of a progressive training in four mathematical sciences, Arithmetic, Geometry, Cosmology (or Astronomy) and Music (or Harmonics). Plato's formal 'encyclopaedia' of the Pythagorean mathemata or disciplines of number was later known as the Quadrivium (or 'Four Ways'). During the Hellenistic period, these intellectually 'cleansing' studies came to be prefaced by the Trivium (or 'Three Ways') of the Verbal Arts - Grammar, Rhetoric and Dialectic (or Logic) - thus completing the educational system of the Seven Liberal Arts (the enkyklios paideia, later called the Studium Generale). Vitruvius repeatedly alludes to this complete system of general education which, for some Romans at least, appears to have become an academic preliminary to training in architecture and other liberal professions (particulary medicine and, presumably, law). ${ }^{14}$

For Vitruvius the science and practice of architecture (ideally at least) begins with a Platonistic system of general education, a formal curriculum culminating in the four Pythagorean mathemata; ${ }^{19}$ and, as with Plato, this encyclical training is a preparation both for professional practice and the higher study of philosophy [Rowland and Howe 1999, 22]. But while his bilingual patron, Caesar Augustus, could easily read between these imperfect lines, Vitruvius fails to make clear to modern readers why the classical architect's academic training in the mathematical arts would ideally be completed by the fourth and final study of Harmonics, the Pythagorean science of musica speculativa (theorica, contemplativa); that is, the philosophy and science of music. The crowning subject of Harmonics was the mathematical structure of the world system or macrocosm which, for the Pythagoreans, was the celebrated 'Harmony of the Spheres'-the cosmic model or template for human art. Vitruvius's sole reference to this grand theme is oblique and perfunctory [De architectura 1.1.16; cf. Rowland and Howe 1999, 24] as is his assertion that

80 GRAHAM PONT- The Education of the Classical Architect from Plato to Vitruvius 
'the architect should know music, in order to have a grasp of canonical and mathematical relations' [Rowland and Howe 1999, 23] — but the allusion is unmistakable.

A pragmatic Roman version of the Hellenistic educational curriculum is taken for granted by Vitruvius but his pedagogy, like his treatise as a whole, is sadly deficient in rational argument, logical order and clarity of expression. As he candidly admits, he was not a great master of grammar, rhetoric or philosophy but just an 'architect who has dipped into literature' [Rowland and Howe 1999, 24]. Vitruvius was a practical man, a minor professional whose elementary knowledge of Greek metaphysics, mathematics and cosmology was apparently acquired mostly through self-education. Fortunately for us, his culture was Hellenistic and bilingual: for all its maddening defects, the Ten Books of Architecture is a unique source of Roman architectural vocabulary and its Greek origins.

\section{From music theory to architectural aesthetics}

In his second chapter, Vitruvius briefly outlines a sophisticated system of aesthetics in analysing the concept of venustas ('beauty', one of his three basic requirements of architecture). This system, like much of his technical vocabulary, is manifestly Greek in origin. Not so obvious is the fact which has eluded many of his translators - that the Vitruvian analysis of beauty was drawn principally from the Greek theory of music (but cf. [Rowland and Howe 1990: 143, 235, 244]).

At least four of the six concepts included under venustas are musical: taxis (which Vitruvius renders as ordinatio), eurythmia and symmetria (both left in their native Greek) and diathesis or dispositio. Vitruvius's technical explanation of taxis as 'consistent proportioning' [Kruft 1994, 25; cf. Rowland and Howe 1999, 24] echoes the older musical (or poetical) sense of melodic and rhythmic order: melodic, as in the 'disposition of notes or intervals in a melody'; and rhythmic, as in 'the disposition of durations' [Michaelides 1978, 321], the longs and shorts of prosody or poetic measure. Dispositio is Vitruvius's rendering of the Greek diathesis, which is not usually remembered as a technical term of music theory; but he himself has left compelling evidence of its musical use in the phrase dispositio tetrachordarum. ${ }^{16}$

Eurythmia means 'beautiful rhythm' [cf. Michaelides 1978, 117] or grace in music generally and in dance in particular; and symmetria strictly means 'commensurable' as in the measured intervals of the musical scale [Michaelides 1978, 307]. According to the great mathematician, astronomer and music theorist, Claudius Ptolemy (fl.127-148AD), 'the more commensurable [intervals] are the more intelligible to the senses' [Michaelides 1978: 307] - a dictum equally applicable to the proportions of music and architecture. The aesthetic use of these three terms almost certainly originated in music, which was not only the most prestigious art of the ancient Greeks but also the theoretical foundation of Western ideas in all the fine arts.

The problem in reading Vitruvius today, however, is to supply the larger scientific, philosophical and educational background of the Greek ideas he inherited-which his book presupposes but which he himself explains imperfectly. Most difficult of all, perhaps, for the modern reader is to see Vitruvius in his true cultural context, as an heir of the PythagoreanPlatonic world-view in which architecture, along with all the other arts, was traditionally modeled on or construed in accordance with musical canons. Thus beauty in architecture was originally explained by a musical rationale. 


\section{Building and architecture: genus and species}

Although Plato does not formalise the relationship of building in general to architecture in particular, a rational ordering of these arts is clearly implied in his contrast between the illiterate manual worker and the well-educated architect: within the general class of buildings (most of which were then and still are built by ordinary, unscientific craftsmen), Plato enables us to identify the distinctive species of scientific constructions which are designed and supervised by intellectual or theoretical builders - that is, by architects properly so-called. It was the theory, of course, rather than the phenomenon being theorised, that was new: for the Greeks (like the Egyptians and Mesopotamians before them) had long since mastered the art of rational or mathematically exact architecture.

Vitruvius echoes Plato in insisting that the architect must be qualified in the knowledge of practical building as well as the intellectual refinements of 'theory and literature'; and his remarks presuppose a similar distinction between the craft of building in general and scientific or mathematical architecture in particular. So, while they are almost three centuries apart, Plato and Vitruvius appear to be in broad agreement on the definition of the architect, the nature of his professional formation and the implicit conception of the art itself. These solid continuities of doctrine cannot have been accidental, given the Roman admiration of almost anything Greek and, especially, the prestige of the Academy which was still flourishing in Vitruvius's time. It is generally accepted that Vitruvius's theoretical conceptions were derived from the lost works of his Greek and Hellenistic predecessors, particularly the architect Hermogenes (c.200 BC) who was about as close to Plato and Vitruvius as the moderns are to Nash and Pugin.

Plato, it seems, must finally be credited yet another philosophical innovation: the first theory of architecture and the first formal curriculum of preliminary architectural studies. The Platonic vision of architecture and architectural didactics has informed the oldest surviving treatise on the Western art; and, like Plato, Vitruvius does not attempt to define architecture as such in his opening paragraphs but confines himself to characterising the professional architect by his appropriate formation and distinguishing him by the knowledge and skills he should ideally possess. ${ }^{17}$

The main implication of their common argument, however, is obvious: architecture is scientific building, that species of design and construction which is distinguished by having a logos or rationale. For the Pythagorean Plato, that rationale was the harmonic proportions of the worldsystem [see McClain 1978] - and the mundane Vitruvius not only acknowledges the charmony of the stars' (De architectura 1, 1, 6) [Rowland and Howe 1999, 24] but also admits the relevance of harmonic ratios to architecture by including his absurdly compressed summary of the Greek scales (De architectura 5, 4) [Rowland and Howe 1999, 66-7]. But, as Alpay Özdural has demonstrated, the Greek harmonic rationale was still valid - more than a thousand years later - for the architecture of the classically encyclopaedic Omar Khayyam. ${ }^{18}$ Even though the rationale has changed, the definition of architecture as scientific, rational or mathematical building is as valid today as it was more than two thousand years ago - and the pedagogical implications are unavoidable! 


\section{Notes}

1. This is how the distinction was translated by A.E. Taylor, whose editors warn against conflating Plato's novel terminology with that later antithesis of 'practical-speculative' or 'practice-theory'-though they rightly concede that 'the technical distinction begins with this passge'; see [Klibansky and Anscombe 1961, 255].

2. This translation by A.E. Taylor. See [Klibansky and Anscombe 1961, 258].

3. In his only other use of fabrica (in the preface to Book 6), Vitruvius speaks as if 'construction technique' (fabrica) is something distinct from 'knowledge of architecture'; see [Rowland and Howe 1999, 76]. Though this usage is inconsistent with his original definitions, it anticipates the modern distinction between architecture proper and mere building, engineering, etc.

4. [Gwilt 1826: 3], etc. The only other correct translation I have seen is that of Francesco di Giorgio Martini: La frabicha e chontinente pensiero circha a l'uso...; see [Scaglia 1985, 75]. P.H. Schrijvers rightly rejects the identification of fabrica and rationcinatio with practice and theory but his alternative contrast between manus et labores (= fabrica) and ratiocinatio et litterae is hardly any better; see [Geertman and de Jong 1989, 52].

5. Having failed to grasp the connection between fabrica and meditatio, Ingrid D. Rowland simply ignores the latter - a serious lapse from her aim of "keeping closely to the Latin text (by making the English text account, one on one, for every single Latin word)"; cf. [Rowland and Howe 1999, 21 and xiii].

6. For practical builders this is a familiar intellectual process: the contemplation and mental solution of a problem, before any actual construction takes place. The fabrica of the modern architect would normally include the ability to think in three spatial dimensions (such as mentally 'sectioning' a solid wall and visualising what is behind it), to imagine alternative design solutions, to recognise by sight the age, style and condition of a building, its approximate dimensions, structural problems or possibilities, and so on.

7. If so, Plato's specific model could have been the choregos (or koryphaeus), the leader, organiser and/or funder of the Athenian dramatic chorus. Given the fundamental importance of Apollo and the Muses in Plato's thought, his ideal architect might have been a kind of Apollo musagetes, the god-like leader and director of a novel chorus of practical Muses whose cooperation in the diverse performing arts of building brought into existence such mighty works as the Parthenon. Plato's musical model is hinted at in his mention of "harmony between partners in a common task" [The Statesman 260B].

8. In a useful discussion of sollertia [Geertman and de Jong 1989, 51] Schrijvers endorses J.J. Pollitt's suggestion that 'the term seems to imply in particular the skill that translates knowledge and thought into action.' This, I believe, is what Plato and Vitruvius had in mind.

9. Schrijvers reaches a similar conclusion (Geertman and de Jong 1989, 51).

10. Cf. Legh 1831, 10: '.. what Vitruvius calls the fabrica of the art... consists in a knowledge of all arts of every sort, absolutely necessary to a building...'.

11. As read by Choisy [1971, 5] and supported by Schrijvers [Geertman and de Jong 1989, 51].

12. Morgan was anticipated by Perrault: la convenance des proportions que doivent avoir les choses que l'on veut fabriquer $[1684,2]$.

13. As Schrijvers concludes; see [Geertman and de Jong 1989, 51].

14. Though very little is known about the formal education of architects in Vitruvius's time [Rowland and Howe 1999,7-8, especially note 59], his older contemporary Varro (116-27BC) adds medicine and architecture to the liberal arts, apparently implying that a general education in the encyclical studies at least sometimes preceded specialised training for these professions - a curriculum structure still found today. See [Hornblower and Spawforth 1996: 1582].

15. Vitruvius's description of those who are 'fully skilled in geometry, astronomy, music and related disciplines' [Rowland and Howe 1999, 24] includes a precise enumeration of the Platonic mathemata in their correct sequence - except for the omission of the preliminary discipline of arithmetic, which is mentioned earlier as a necessary part of the architect's training; see [Rowland and Howe 1999, 22].

16. De architectura 5, 4, 3. Diathesis and dispositio are briefly commented on by Rowland and Howe [1999, 149]. There is an interesting discussion of these terms in Essay VI of [Legh 1831].

17. In his second chapter, however, Vitruvius proceeds to analyse the 'Terms of Architecture' [Rowland and Howe 1999, 24ff.], a five-fold classification of the subject which, clearly Greek in inspiration, reveals the 
impressive progress made in architectural theory after Plato. Vitruvius's few references to Plato belie his actual dependence on Platonic theory and tradition, imbibed mainly, no doubt, from derivative textbooks.

18. See [Özdural 2002], especially 175ff. on Khayyam's architectural use of the 'musical proportion'. I was fortunate to meet the late Professor Özdural at the Nexus 2002 Conference (Óbidos, Portugal, June 2002) where he presented an outstanding paper - historically erudite, mathematically sophisticated and architecturally very enlightening.

\section{Bibliography}

Callebat, Louis and Phillipe Fleury. 1995. Dictionnaire des terms techniques du De architectura de Vitruve. Hildesheim, etc. Olms-Weidemann.

H. Geertman and J.J. DE JONG (ed.), 1989. Munus non ingratum. Proceedings of the International Symposium on Vitruvius's De Architectura and the Hellenistic and Republican Architecture. Leiden, 2023 January 1987. Leiden: Babesch.

Granger, Frank, trans. 1962. On Architecture, by Vitruvius. 2 vols. London: William Heinemann; Cambridge: Harvard University Press.

Hornblower, Simon and Anthony Spawforth, eds. 1996. The Oxford Classical Dictionary. 3rd ed. Oxford: Oxford University Press.

HoYle, John. 1770. Dictionarium musica, being a complete dictionary; or, treasury of music... London: the author.

GWILT, Joseph, trans. 1826. The Architecture of Marcus Vitruvius Pollio, in ten books. Translated from the Latin. London: Priestley and Weale.

KlibansKy, Raymond and Elizabeth Anscombe. 1961. Plato: the Sophist and the Statesman. Translation and Introduction by A.E. Taylor. London: Thomas Nelson and Sons.

KRUfT, Hanno-Walter. 1994. A History of Architectural Theory from Vitruvius to the Present. New York: Princeton Architectural Press.

LEGH, Peter. 1831. The music of the eye; or, essays on the principles of the beauty and perfection of Architecture... London: William Walker.

Mathiesen, Thomas J. 1983. Aristides Quintilianus On Music; Translation, with Introduction, Commentary and Annotations... New Haven and London: Yale University Press.

MiCHAELIDES, Solon. 1978. The music of ancient Greece: An encyclopaedia. London: Faber and Faber.

MCClain, Ernest G. 1978. The Pythagorean Plato: Prelude to the Song Itself. Stony Brook: Nicolas Hays.

Morgan, Morris Hicky (trans). 1960. The Ten Books on Architecture, by Vitruvius. New York: Dover Publications.

ÖZDURAL, Alpay. 2002. The Use of Cubic Equations in Islamic Art and Architecture. Pp. 165-179 in Nexus IV: Architecture and Mathematics, ed. José Francisco Rodrigues and Kim Williams (Fucecchio: Kim Williams Books, 2002).

Perrault, Claude. 1684. Les dix livres d'architecture de Vitruve corrigez et tradvits.... 2nd ed. Paris, Jean Baptiste Coignard.

Ross, W.D. 1954. Ethica Nicomachea. Vol.IX of The Works of Aristotle. Oxford: Oxford University Press.

Rowland, Ingrid D. and Thomas Noble Howe, trans. 1999. Ten Books on Architecture, by Vitruvius. Cambridge: Cambridge University Press.

SCAGLIA Gustina, ed. 1985. Il "Vitruvio Magliabechiano" di Francesco Giorgio Martini. Firenze: Edizioni Gonnelli.

84 GRAHAM PONT- The Education of the Classical Architect from Plato to Vitruvius 


\section{About the author}

Graham Pont taught in the General Education programme at the University of New South Wales for thirty years. Here he introduced the world's first undergraduate courses in Gastronomy (1978-88). He was a founding convener of the Symposium of Australian Gastronomy (1984) and co-editor of Landmarks of Australian Gastronomy (1988). His last appointments were a visiting professorship in the School of Science and Technology Studies, UNSW (1996-99) and a visiting fellowship to Clare Hall, Cambridge (1997-8).

Trained in philosophy, his principal research area has been history and philosophy of music. In 2000 he published the results of the first major computer analysis of Handel's music and he is completing a biography of Australia's first composer and musicologist, Isaac Nathan (1792-1864). A long study of Pythagorean ideas has proved unexpectedly relevant to his latest enthusiasm: the design philosophy of Walter Burley and Marion Mahony Griffin. 